\title{
Acute immune thrombocytopaenic purpura in a patient with COVID-19 and decompensated cirrhosis
}

\author{
Florent Artru, ${ }^{1}$ Lorenzo Alberio, ${ }^{2}$ Darius Moradpour, ${ }^{1}$ Grégoire Stalder (1) ${ }^{2}$
}

${ }^{1}$ Service of Gastroenterology and Hepatology, Centre Hospitalier Universitaire Vaudois, Lausanne, Switzerland ${ }^{2}$ Service and Central Laboratory of Hematology, Centre Hospitalier Universitaire Vaudois, Lausanne, Switzerland

\section{Correspondence to}

Dr Grégoire Stalder; gregoire.stalder@chuv.ch

Accepted 28 June 2020

Check for updates

(c) BMJ Publishing Group Limited 2020. No commercial re-use. See rights and permissions. Published by BMJ.

To cite: Artru F, Alberio L, Moradpour D, et al. BMJ Case Rep 2020;13:e236815. doi:10.1136/bcr-2020-

236815

\section{SUMMARY}

We report on a patient with coronavirus disease 2019 (COVID-19) and decompensated cirrhosis who experienced a favourable outcome of severe immune thrombocytopaenic purpura (ITP) after administration of intravenous immunoglobulin and high-dose dexamethasone. The present case suggests that it is reasonable to evoke ITP in case of profound thrombocytopaenia in a patient with COVID-19.

\section{BACKGROUND}

Published data suggest that poor outcome of severe acute respiratory syndrome coronavirus 2 (SARS-CoV-2) infection is related to an excessive inflammatory reaction.

Recent publication suggest poor outcomes in patients with coronavirus disease 2019 (COVID19) and pre-existing advanced chronic liver disease.

Only scarce information is available regarding the management of SARS-CoV-2-related haematological disorders.

\section{CASE PRESENTATION}

We report on a 38-year-old obese patient with decompensated cirrhosis (Child-Pugh C10) and IgA nephropathy who was hospitalised on 1 April 2020 in the context of COVID-19 documented by positive PCR for SARS-CoV-2 on nasopharyngeal swab. Cirrhosis was due to alcoholic liver disease, likely aggravated by concomitant non-alcoholic steatohepatitis, and was complicated by refractory ascites since 4 months. During the 10 days preceding admission, the patient developed asthenia, fever and rapidly worsening cough associated with dyspnoea at rest. On admission, he was febrile at $39^{\circ} \mathrm{C}$ and had a respiratory rate of 35 per minute. The oxygen saturation was $85 \%$ while breathing ambient air and he required $6 \mathrm{~L}$ per minute of oxygen in the context of worsening pneumonia. Chest X-ray showed the presence of bilateral peripheral airspace opacities. C reactive protein was $31 \mathrm{mg} / \mathrm{L}$ (normal range, $<10 \mathrm{mg} / \mathrm{L}$ ), procalcitonin $0.41 \mu \mathrm{g} / \mathrm{L}$ (normal range, $0.10-0.49 \mu \mathrm{g} / \mathrm{L}$ ), ferritin $1120 \mu \mathrm{g} / \mathrm{L}$ (normal range, $\quad 12-300 \mu \mathrm{g} / \mathrm{L}$ ) and D-dimers $7828 \mathrm{ng} /$ $\mathrm{mL}$ (normal range, $<500 \mathrm{ng} / \mathrm{L}$ ). The patient was treated with hydroxychloroquin $(600 \mathrm{mg} /$ day $)$ and co-amoxicillin/clavulanic acid $(4800 \mathrm{mg} /$ day) during the first 4 days. Laboratory tests performed over the next days showed a rapid decrease of platelet count from baseline values around $70 \mathrm{~g} / \mathrm{L}$ (chronic moderate thrombocytopaenia due to liver

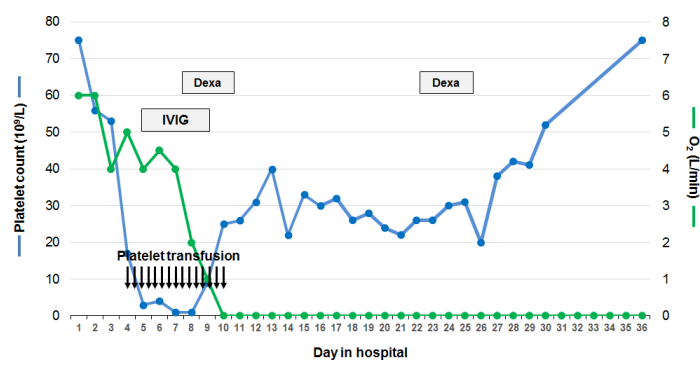

Figure 1 Clinical course and treatments administered during hospitalisation. Platelet counts (blue line) decreased rapidly to $<20 \mathrm{~g} / \mathrm{L}$. As the patient developed severe epistaxis, platelet transfusion was initiated (arrows), however without response. Due to profound thrombocytopaenia (1 g/L) and persistent epistaxis, intravenous immunoglobulin (IVIG $0.4 \mathrm{~g} / \mathrm{kg}$ per day for 5 days) and dexamethasone ( $40 \mathrm{mg} /$ day for 4 days) were administrated, enabling platelet count stabilisation around $30 \mathrm{~g} / \mathrm{L}$ and resolution of epistaxis without any further platelet transfusion. Meanwhile, oxygen requirements (green line) decreased and the patient was well on ambient air by day 10 . A secondary drop in platelet counts to $22 \mathrm{~g} / \mathrm{L}$ on day 21 has motivated the administration of a second cycle of dexamethasone, resulting in return of platelet counts to baseline values.

disease and hypersplenism) to a nadir of $1 \times 10^{9} / \mathrm{L}$ (figure 1). Because of severe epistaxis, platelet transfusions were administered, however with no response. A blood smear confirmed severe thrombocytopaenia and did not show any schistocytes; coagulation studies allowed to exclude disseminated intravascular coagulation (DIC), anti-platelet factor 4/heparin antibodies were not detected, testing for viral hepatitis, HIV, cytomegalovirus, Epstein-Barr virus and varicella zoster virus was negative. Hence, a diagnosis of likely SARS-CoV-2-related immune thrombocytopaenic purpura (ITP) was retained. Intravenous immunoglobulin (IVIG) $\quad(0.4 \mathrm{~g} / \mathrm{kg}$ per day for 5 days) and high-dose dexamethasone $(40 \mathrm{mg} /$ day for 4 days) were initiated, resulting in rapid improvement of platelet counts and cessation of epistaxis (figure 1).

\section{OUTCOME AND FOLLOW-UP}

After a transient stabilisation, platelet counts dropped again slowly to $22 \mathrm{~g} / \mathrm{L}$ on day 21 . Hence, a second cycle of dexamethasone $(40 \mathrm{mg} /$ day for 4 days) was administered and followed by a rapid increase in platelet counts to the patient's baseline values (75 g/L at day 36). Of note, the patient 


\section{Learning points}

- In case of severe acute respiratory syndrome coronavirus 2 (SARS-CoV-2) and severe thrombocytopaenia, it is reasonable to consider a diagnosis of immune thrombocytopaenia (ITP).

- Treatment of ITP in the context of coronavirus disease 2019 (COVID-19) with high-dose dexamethasone and intravenous immunoglobulin (IVIG) appears to be effective.

- Treatment with high-dose dexamethasone and IVIG may have promoted a favourable course of COVID-19 in this decompensated cirrhotic patient.

underwent three ascites taps. Two of them were performed when platelet counts were $<20 \mathrm{~g} / \mathrm{L}$, without any bleeding complication. The large volume paracenteses may have helped improving lung ventilation. The course of pneumonia was also favourable and liver as well as renal functions could be stabilised. The patient did not experience any bacterial superinfection.

\section{DISCUSSION}

In line with a recent report, it is reasonable to evoke ITP in case of profound thrombocytopaenia in a patient with COVID-19. ${ }^{1}$ Indeed, the emergence of autoimmune diseases in the context of SARS-CoV-2 is increasingly reported. ${ }^{2}$ The differential diagnosis of thrombocytopaenia in a cirrhotic patient with COVID-19 includes splenic sequestration, consumption within large thrombi, DIC and sepsis-induced thrombocytopaenia. Indeed, severe SARS-CoV-2 infection is associated with coagulopathy, although thrombocytopaenia is usually moderate. ${ }^{3}$ In this case, the kinetics of the onset of thrombocytopaenia, its depth, the absence of even a transient response to platelet transfusions, the stability of coagulation parameters and the response to treatment with IVIG and dexamethasone provide reasonable evidence of an immune origin to thrombocytopaenia. ${ }^{4}$

Treatment with IVIG and the two cycles of dexamethasone has likely resulted in improvement of platelet counts ${ }^{4}$ that eventually returned to the baseline values of the patient. Importantly, the patient also experienced a favourable course of COVID-19 pneumonia. Hence, one may speculate that IVIG and dexamethasone had a beneficial impact on the excessive inflammatory reaction associated with SARS-CoV-2 infection, ${ }^{5}$ contributing to the favourable clinical course of the pneumonia observed in our patient. Of note, this outcome is remarkable also in light of recent data indicating an increased mortality from COVID-19 in patients with pre-existing liver disease and, notably, cirrhosis. ${ }^{6}$ However, more data are needed to validate this hypothesis and to assess the clinical course of COVID-19 in patients with cirrhosis as well as the incidence of ITP and the effects of its treatment in the setting of SARS-CoV-2 infection.

Contributors FA and GS conceived the study, performed the literature research and wrote the paper. LA and DM wrote, commented and corrected the manuscript.

Funding The authors have not declared a specific grant for this research from any funding agency in the public, commercial or not-for-profit sectors.

Competing interests None declared.

Patient consent for publication Obtained.

Provenance and peer review Not commissioned; externally peer reviewed.

This article is made freely available for use in accordance with BMJ's website terms and conditions for the duration of the covid-19 pandemic or until otherwise determined by BMJ. You may use, download and print the article for any lawful, non-commercial purpose (including text and data mining) provided that all copyright notices and trade marks are retained.

\section{ORCID iD}

Grégoire Stalder http://orcid.org/0000-0002-0536-5418

\section{REFERENCES}

1 Zulfiqar A-A, Lorenzo-Villalba N, Hassler P, et al. Immune thrombocytopenic purpura in a patient with Covid-19. N Eng/ J Med 2020;382:e43.

2 Galeotti C, Bayry J. Autoimmune and inflammatory diseases following COVID-19. Nat Rev Rheumatol 2020. doi:10.1038/s41584-020-0448-7. [Epub ahead of print: 04 Jun 2020].

3 Connors JM, Levy JH. COVID-19 and its implications for thrombosis and anticoagulation. Blood 2020;135:2033-40.

4 Cooper N, Ghanima W. Immune thrombocytopenia. N Engl J Med 2019:381:945-55.

5 Mehta P, McAuley DF, Brown M, et al. COVID-19: consider cytokine storm syndromes and immunosuppression. Lancet 2020;395:1033-4.

6 Singh S, Khan A. Clinical characteristics and outcomes of COVID-19 among patients with pre-existing liver disease in United States: a multi-center research network study. Gastroenterology 2020. [Epub ahead of print: 03 May 2020].

Copyright 2020 BMJ Publishing Group. All rights reserved. For permission to reuse any of this content visit

https://www.bmj.com/company/products-services/rights-and-licensing/permissions/

BMJ Case Report Fellows may re-use this article for personal use and teaching without any further permission.

Become a Fellow of BMJ Case Reports today and you can:

- Submit as many cases as you like

- Enjoy fast sympathetic peer review and rapid publication of accepted articles

- Access all the published articles

Re-use any of the published material for personal use and teaching without further permission

Customer Service

If you have any further queries about your subscription, please contact our customer services team on +44 (0) 2071111105 or via email at support@bmj.com.

Visit casereports.bmj.com for more articles like this and to become a Fellow 